U.S. Department of the Interior

U.S. Geological Survey

\title{
GEOLOGIC MAPS OF THE MOUNT GUYOT, LUFTEE KNOB, AND COVE CREEK GAP 7.5-MINUTE QUADRANGLES, GREAT SMOKY MOUNTAINS NATIONAL PARK, TENNESSEE AND NORTH CAROLINA
}

by Art Schultz

USGS Reston, VA

Open-File Report 99-536

This report is preliminary and has not been reviewed for conformity with the U.S. Geological Survey editorial standards or with the North American Stratigraphic Code. Any use of trade, product, or firm names is for descriptive purposes only and does not imply endorsement by the U.S. Government. 


\section{INTRODUCTION}

This report was prepared at the request of the Great Smoky Mountains National Park (GSMNP) as part of a U.S. Geological Survey (USGS)-National Park Service (NPS) cooperative agreement. Geologic map data from this report and from other quadrangles will be used by GSMNP in the preparation of a digital geologic database and a new 1:100,000-scale bedrock and surficial geologic map of the GSMNP.

The geologic maps (Plates 1-3, Figure 1) were prepared by compiling existing geologic data of 1:62,500-scale from Hadley and Goldsmith (1963). Contacts and selected structural data were plotted on 1:24,000-scale topographic base maps. These data were then field checked from outcrops along roads and trails. Additionally, off-trail traverses were made in selected areas to delineate the extent and nature of the surficial deposits. Modern debris flows in the Mount Guyot quadrangle were mapped from aerial photographs taken in 1995. These are similar to those mapped by Bogucki (1970) and Schultz (1998) in the Mount LeConte 7.5-min quadrangle. Modern debris flows were mapped in 1998-1999.

\section{GEOLOGIC SETTING}

The geology of GSMNP is summarized in King and others (1968), and the geology of the Mount Guyot, Luftee Knob and Cove Creek Gap 7.5-min. quadrangles is discussed in detail by Hadley and Goldsmith (1963). A regional tectonic syntheses, which includes the area of GSMNP, can be found in Hatcher (1989), and an extensive reference list accompanies a recent study by Montes (1997). A non-technical summary and guide to the geology of the Park can also be found in Harry L. Moore (1988). Additionally, a visitor's type geologic map and text on the rock types and tectonic setting of GSMNP and surrounding area is found in Schultz and Southworth (1999). Recently published geologic quadrangle reports from the USGS-NPS cooperative are Southworth (1995), Schultz(1998), and Southworth and others, 1999.

GSMNP lies within the Appalachian Blue Ridge geologic and physiographic province. Bedrock in the area of this report consists of a thick sequence of metamorphosed Late Proterozoic (800-545 million years old) sandstone, siltstone, shale, and conglomerate and metamorphosed Middle Proterozoic (about 1.1 billion years old) granitic gneiss. The metasedimentary rocks have been divided into two groups on the basis of rock characteristics. Metasedimentary rocks of the Snowbird Group include from oldest to youngest, the Wading Branch Formation, Longarm Quartzite, Pigeon Siltstone, Roaring Fork Sandstone, and Rich Butt Sandstone. This sequence of rocks is interpreted to be the oldest of the metasedimentary rocks in the park and is overlain by the Greenbrier fault and Elmont Sandstone, Thunderhead Sandstone, and Anakeesta Formation of the Great Smoky Group (Hadley and Goldsmith, 1963). Rocks of the Snowbird Group are thought to be older than rocks of the Great Smoky Group. The metasedimentary rocks overlie Middle Proterozoic granitic gneiss along faults and unconformities. These rocks have undergone biotite-garnet grade metamorphism (Hadley and Goldsmith, 1963), and summaries of available data on the timing of metamorphism are found in Drake and others (1989).

The rocks in the area are folded, cleaved, faulted, fractured, and jointed (Hadley and 
Goldsmith, 1963). The Greenbrier fault probably formed prior to the regional metamorphism, about 450 million years ago. Other faults in the quadrangles probably occurred during the Alleghanian orogeny, approximately 250 million years ago. Formation of cleavage and folds is thought to have occurred both prior to and during the Alleghanian orogeny (Hadley and Goldsmith,1963).

The surficial geology in the study area consists of alluvium and terraces along modern low-elevation drainages, and extensive boulder colluvium and boulder debris deposits at higher elevations. Also, a few modern debris flow deposits occur in the southern part of the Mount Guyot 7.5-minute quadrangle.

Terrace deposits and alluvium are fluvial in origin and characteristically contain both coarse and fine material. At lower elevations, cobbles and boulders are well rounded and are in a fine-grained sandy matrix. Alluvium along steep gradient streams at high elevations consists only of poorly rounded, coarse boulders and cobbles with very minor finer material.

Colluvium consists dominantly of boulders and cobbles derived from weathering of bedrock, and transported downslope chiefly by gravity. However, some areas mapped as colluvium also contain boulder streams and boulder fields that may have formed in periglacial environments at the higher elevations during the latter part of the Pleistocene (Delcourt and Delcourt, 1985). In the boulder streams and boulder fields, gravity, solifluction, freeze-thaw ice wedging, and ice rafting contributed to downslope movement. In general, the surface of the colluvium and the periglacial deposits contains little or no matrix or fine-grained material, such as soil, sand, or clay. Additionally, the very coarse boulder streams, boulder fields, and colluvium often do not have extensive trees and other vegetation growing on them and are usually very well drained, often with springs emergent from their toes. No evidence of present day movement is obvious.

Debris deposits are believed to be the result of ancient, large debris flows and floods that carried large boulders and cobbles down steep-walled valleys and deposited them as fans on the lower slopes. These deposits usually have a finer-grained matrix and are soil covered. Today, these deposits are tree covered, stable on the slope, and are being incised by the present streams. Both the size of the deposits and the contact between debris deposits and colluvium is usually gradational.

Modern debris flows are limited to the area on the highest slopes underlain by slate and metasiltstone of the Anakeesta Formation. The debris flows are the result of very high rainfall during storms and consist of weathered and fresh bedrock, soil, and vegetation, including trees, shrubs, bushes, and grass. These debris flows pose a hazard to trail hikers and motorists in the park. Whenever several days of heavy rain have occurred, debris flows may occur in this part of the park.

REFERENCES CITED:

Bogucki, D.J., 1970, Debris slides and related flood damage associated with the September 1, 1951, cloudburst in the Mt. Le Conte-Sugarland Mountain area, Great Smoky Mountains National Park: Ph.D. dissertation, Univ. of Tennessee, Knoxville, 165 pp.

Delcourt, P.A., and Delcourt, H.R., 1985, Dynamic Quaternary landscapes of East Tennessee: an integration of paleoecology, geomorphology, and archaeology, Field trip 7, in Field trips of the Southern Appalachians, SEGSA 1985, Univ. Of Tennessee, Dept. Of Geol. Sciences, Studies in Geology 9, p. 191-220. 
Drake, A.A. Jr., Sinha, A.K., Laird, John, and Guy, R.E., 1989, The Taconic orogen, in. Hatcher, R.D., Jr., Thomas, W.A., and Viele, G.W., eds., The Appalachian-Ouachita Orogen in the United States, The Geology of North America: Geological Society of America, Boulder, Colorado, v. F-2, p. 101-177.

Hadley, J.B., and Goldsmith, Richard, 1963, Geology of the eastern Great Smoky Mountains, North Carolina and Tennessee: U.S. Geological Survey Professional Paper 349-B, 118p., 1:62,500 scale map.

Hatcher, R.D., Jr., 1989, Tectonic synthesis of the U.S. Appalachians, in Hatcher, R.D., Jr., Thomas, W.A., and Viele, G.W., eds., The Appalachian-Ouachita orogen in the United States, The geology of North America: Geological Society of America, Boulder, Colorado, v. F-2, p. 511-535.

King, P.B., Newman, R.B., and Hadley, J.B., 1968, Geology of the Great Smoky Mountains National Park, Tennessee and North Carolina: U.S. Geological Survey Professional Paper 587, 23p., 1:125,000 scale map.

Montes, Camilo, 1997, The Greenbrier and Hayesville faults in central-western North Carolina, M.S. Thesis, The University of Tennessee, Knoxville, Tennessee, $114 \mathrm{p}$.

Moore, H.L., 1988, A roadside guide to the geology of the Great Smoky Mountains National Park: The University of Tennessee Press, Knoxville, Tennessee, $178 \mathrm{p}$.

Schultz, Art, 1998, Geologic map of the Mount LeConte 7.5 min. quadrangle, Great Smoky Mountains National Park, Tennessee and North Carolina: U. S. Geological Survey OpenFile Report 98-32, 10 p. and 1:24,000 scale map.

Schultz, Art, and Southworth, Scott, 1999, Geology and geologic history of Great Smoky Mountains National Park: Visitor's geologic map and text: Great Smoky Mountains Natural History Association Special Publication "Geology", 1:175,000 scale map and text.

Southworth, Scott, 1995, Preliminary geologic map of the Great Smoky Mountains National Park within the Fontana Dam and Tuskeegee quadrangles, Swain County, North Carolina: U.S. Geological Survey Open-File Report 95-264, 33p. and 1:24,000 scale map.

Southworth, Scott, Chirico, Peter, and Putbrese Trevor, 1999, Geologic map of parts of the Cades Cove and Calderwood Quadrangles, Tennessee and North Carolina, Great Smoky Mountains National Park: U.S. Geological Survey Open-File Report 99-175, 1:24,000scale map. 


\section{DESCRIPTION OF MAP UNITS}

Alluvium (Holocene) - Unconsolidated clay, silt, sand, cobbles, and boulders found along

Qa floodplains and streams. Much of the alluvium is very coarse and consists of boulders reworked from nearby extensive debris and colluvial deposits. In places, small outcrops of bedrock may be exposed in the river bottoms during times of lower river levels. These outcrops are shown on the map by structural map symbols. Thickness from 1 to 30 feet.

Debris flow (Holocene) - Debris flow track and deposit. The deposits consist of varying

Qdf amounts of slab-like boulders, cobbles, and pebbles of metamorphosed sandstone, siltstone, and slate in a fine matrix of soil, clay, and vegetation including trees, grass, and brush. Thickness from 5 to about 30 feet.

Colluvium (Holocene and Pleistocene)- Boulder streams, boulder fields, and talus containing Qc minor alluvium and debris. Boulder streams and boulder fields are chiefly Pleistocene in age, colluvium ranges from Pleistocene or older to Holocene. Deposits are chiefly accumulations of sub-rounded boulders and cobbles of metamorphosed sandstone and minor amounts of metamorphosed siltstone and shale. Generally found as clast-supported diamicton and rarely matrix supported. Surface of deposit consistently blocky and devoid of finer material. Often poorly-vegetated and found on the higher steep slopes as talus near bedrock escarpments and as fill in steep-walled mountain gorges and hollows. Deposits may grade down slope into more debris-like deposits, and contacts between colluvial and debris-flow deposits are often transitional. Thickness from 10 to 100 (?)
feet.

Terrace deposits (Holocene and Pleistocene?)- Unconsolidated clay, sand, gravel, cobbles, and

Qt boulders. Large clasts are chiefly metamorphosed sandstone with minor amounts of metamorphosed siltstone and shale. Generally located more than 20 to 30 feet above the present floodplain. Some areas of terraced bedrock have very little of the deposit remaining. Thickness from 10 to 30 (?) feet

Debris (Pleistocene)- Dominantly matrix-supported siliciclastic diamicton on lower slopes and

Qd valley bottoms consisting of boulders, cobbles, and pebbles of metamorphosed sandstone, siltstone, and shale in a matrix of pebbles, sand, silt, and clay. Deposits generally are vegetated with some boulders and cobbles scattered across the surface. Fan-like morphology and matrix-supported texture suggest that these deposits are ancient debris-flow fans. Thickness from 10 to as much as 100 feet. 
Anakeesta Formation ( Late Proterozoic)- Dark-gray, fine-grained slate and phyllite interbedded

$\mathrm{Za}$ with dark-gray metasiltstone and fine-grained gray metasandstone. Includes minor discontinuous dolomite lenses. Base is placed above highest conglomerate in the Thunderhead Sandstone; top has been removed by erosion. Thickness from 1,800 to 2,400 feet.

Upper sandstone member- Light-greenish-gray fine- to medium-grained metasandstone. Upper Zas contact not present. Lower contact placed at first appearance of thick ( 15 feet) mediumgrained sandstone. Thickness from 1,000 to 1,500 feet.

Thunderhead Sandstone (Late Proterozoic)- Light-gray, medium- to coarse-grained feldspathic

$\mathrm{Zt}$ metasandstone or arkose, interbedded with arkosic pebble metaconglomerate, finegrained feldspathic metasandstone, argillaceous metasandstone, and dark-gray slate. Base is below lowermost metaconglomerate; top is at highest metaconglomerate that usually forms massive cliffs. Thickness approximately 6,000 feet.

Elkmont Sandstone (Late Proterozoic)- Medium- to dark-gray, medium- to fine-grained, highly $\mathrm{Ze}$ feldspathic metasandstone and gray, fine-grained argillaceous metasandstone and slate. Base not exposed. Top is just below lowermost metaconglomerate in Thunderhead Sandstone. Thickness approximately 3,000 feet.

Rich Butt Sandstone (Late Proterozoic)- Light-gray, fine-grained metasandstone and medium- to $\mathrm{Zrb}$ dark-gray metasiltstone and shale. Top is not exposed in the study area; base is below Zrbp lowermost thick-bedded meta-sandstone with dark metasiltstone and shale layers and above meta-siltstone of the Pigeon Siltstone. In the eastern part of the mapped area, the Rich Butt Sandstone is more argillaceous, particularly in the lower part of the section, than elsewhere and consists of dark gray slate and metasiltstone, similar to the dark slates of the Anakeesta Formation. Thickness approximately 4,000 feet.

Pigeon Siltstone (Late Proterozoic)- Medium- to dark-greenish-gray and dark-grayish-olive,

$\mathrm{Zp}$ metasiltstone, slate, and fine-grained metasandstone. Top of the formation is last metasiltstone bed below more massive metasandstone of the overlying Rich Butt Sandstone; the base is placed above resistant, 10-foot-thick, feldspathic-rich, coarsegrained metasandstone in the Roaring Fork Sandstone. Thickness from 3,000 to 6,000 feet.

Roaring Fork Sandstone (Late Proterozoic)-Dark-greenish-gray, fine- to medium-grained, $\mathrm{Zr}$ feldspathic metasandstone, metasiltstone, and minor amounts of slate and muscovite phyllite. Soft sediment folds are common in some beds. The top of the formation is placed at the highest, thick, resistant coarse-grained metasandstone; the base is not exposed. Thickness approximately 7,000 feet. 
Longarm Quartzite-(Late Proterozoic)- Light to medium greenish-gray to light pinkish gray,

$\mathrm{Zl}$ medium to coarse-grained quartzite and metasandstone. Thin, dark laminations and cross bedding is common. The top of the formation is gradational and the boundary is located where the light-colored feldspathic quartzite changes to darker metasandstone and metasiltstone of the Roaring Fork Sandstone. The base is placed where light colored, cross-bedded, feldspathic quartzite of the Longarm rests on dark metasandstone and schistose metasandstone of the Wading Branch Formation. Approximately 5000 feet
thick.

Wading Branch Formation-(Late Proterozoic)-Medium to dark gray metasandstone, slaty $\mathrm{Zw}$ metasiltstone and coarse pebble metaconglomerate. The lower part of the formation consists of a pale-green schist with thin metasandstone layers which rest unconformably on Middle Proterozoic granitic gneiss. The thickness is about 1500 feet.

Basement rocks undifferentiated-(Middle Proterozoic)-augen and layered gneiss, mylonitic Yg gneiss, schist, amphibolite, granodiorite, granitic gneiss, and pegmatite. 


\section{EXPLANATION OF MAP SYMBOLS}

contact; dashed where concealed

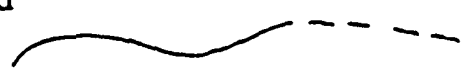

strike and dip of beds-inclined

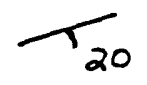

strike of beds-vertical

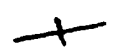

strike and dip of beds-overturned

$$
f_{20}
$$

strike and dip of cleavage-inclined

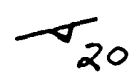

trace of axis of regional scale anticline showing plunge direction

$$
--\frac{\hat{f}}{\downarrow}-\longrightarrow
$$

trace of axis of regional scale syncline

$$
\ldots-\ldots
$$

trace of axis of overturned syncline

$$
-\ldots+\ldots
$$

Greenbriar thrust fault, teeth on upper plate; dotted where concealed

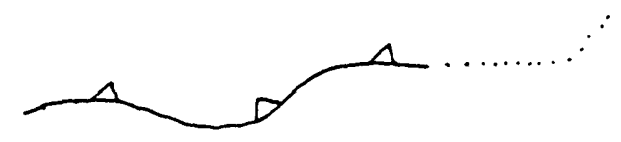

high-angle fault, $\mathrm{R}$ on hanging wall; dotted where concealed

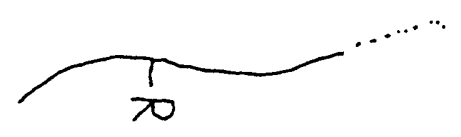




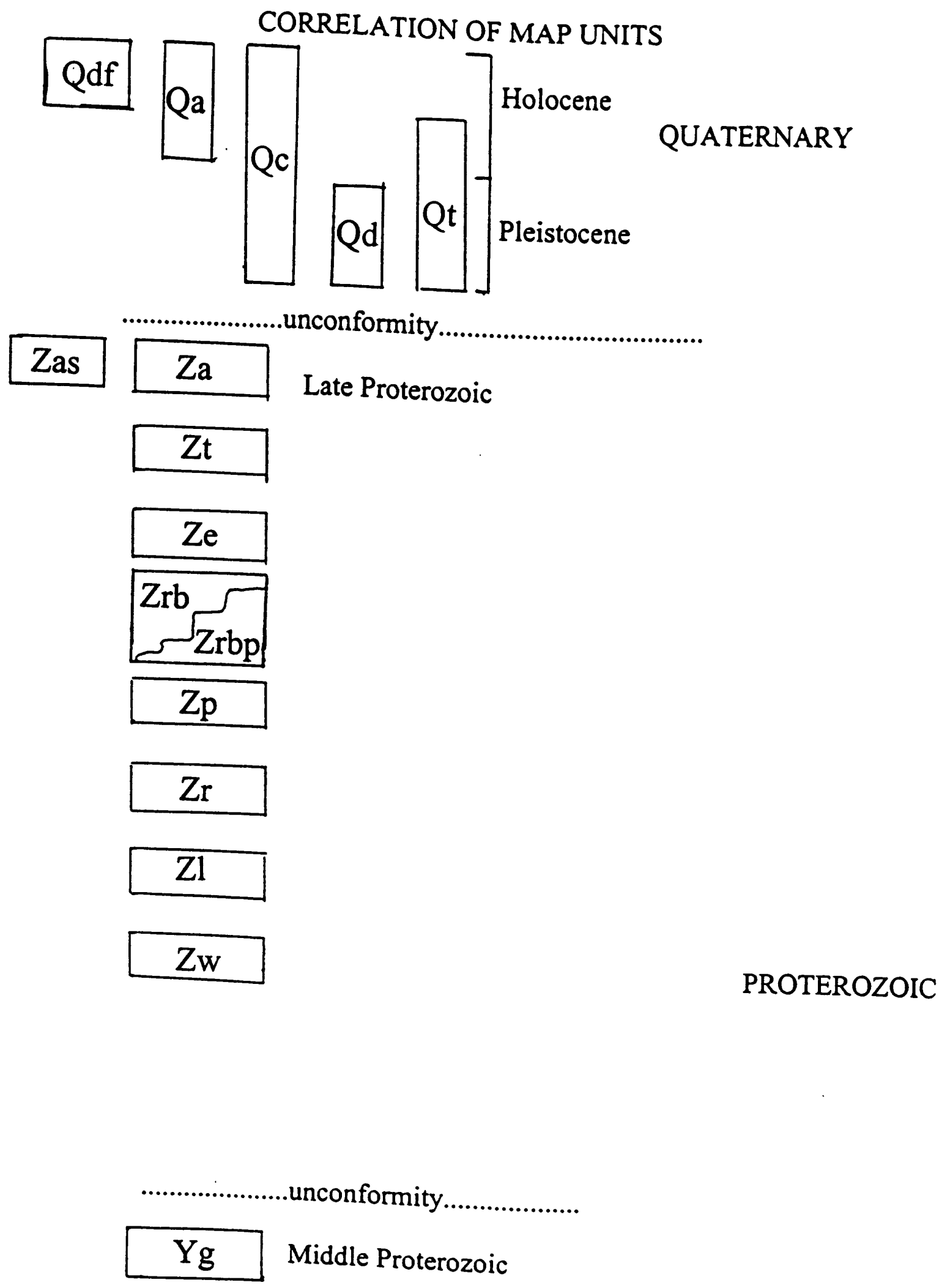




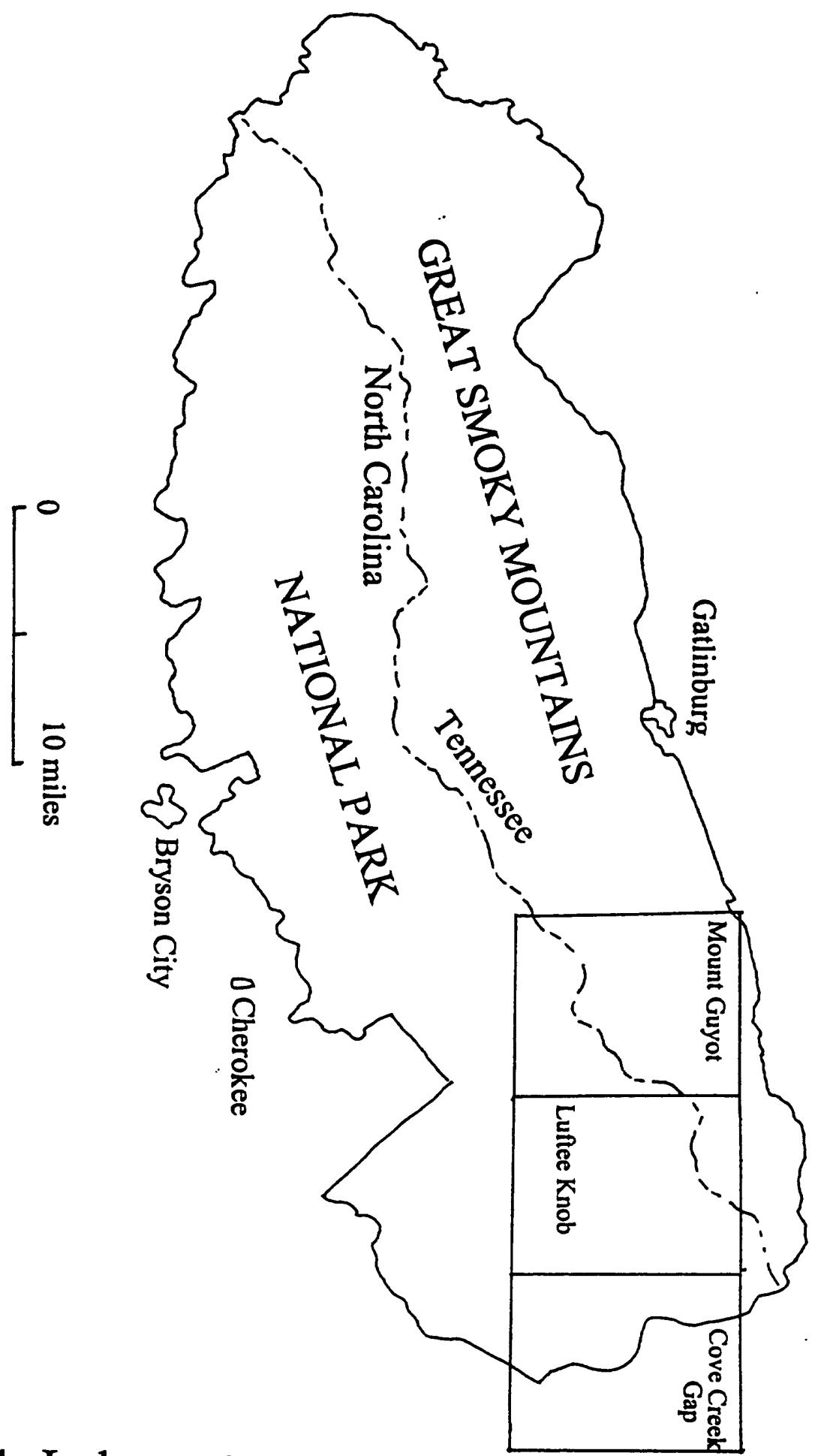

Figure 1. Index to Plates 1-3, 7.5-minute quadrangle locations. 